\title{
Genetic effect of the prolactin receptor gene on egg production traits in chickens
}

\author{
L. Zhang ${ }^{1 *}$, D.Y. Li ${ }^{1 *}$, Y.P. Liu ${ }^{1}$, Y. Wang ${ }^{1}$, X.L. Zhao ${ }^{2}$ and Q. Zhu ${ }^{1}$ \\ ${ }^{1}$ Institute of Animal Genetics and Breeding, Sichuan Agricultural University, \\ Ya'an, P.R. China \\ ${ }^{2}$ College of Animal Science and Technology, Sichuan Agricultural University, \\ Ya'an, P.R. China \\ *These authors contributed equally to this study. \\ Corresponding author: Q. Zhu \\ E-mail: zhuqing5959@163.com
}

Genet. Mol. Res. 11 (4): 4307-4315 (2012)

Received December 7, 2011

Accepted June 4, 2012

Published October 2, 2012

DOI http://dx.doi.org/10.4238/2012.October.2.1

\begin{abstract}
The identification and utilization of potential candidate genes with significant effects on economically important traits have become increasingly important in poultry breeding programs. The prolactin (PRLR) receptor is a specific receptor for prolactin, which is an anterior pituitary peptide hormone involved in various physiological activities and is essential for reproductive success. In chickens, the PRLR gene resides on the $\mathrm{Z}$ chromosome. We used a pooled DNA sequencing approach for identifying SNPs of the PRLR gene. Three hundred and ninesix Erlang Mountainous chicken hens were genotyped for six SNPs using PCR-SSCP and PCR-sequencing methods; the association with chicken egg production traits was studied using general linear model procedures. Three linked SNPs (G14952A, A14969C and G14984A) at the P1 locus, two linked SNPs (G17560A and T17626A) at the P2 locus, and one SNP (T20868C) at the P3 locus were identified. Eight haplotypes were reconstructed on the basis of the six SNPs. The general linear model analysis indicated that there were significant associations of certain genotypes and
\end{abstract}


haplotypes with some egg production traits. We conclude that chicken PRLR gene polymorphisms are associated with egg production traits and have potential as molecular markers for chicken breeding.

Key words: DNA polymorphism; PRLR gene; Egg production traits; Chicken

\section{INTRODUCTION}

Prolactin (PRL) was originally identified because of its capability of stimulating mammary gland development and lactation. PRL is an anterior pituitary hormone that, along with growth hormones and placental lactogens, belongs to a family of hormones that probably resulted from the duplication of an ancestral gene (Sinha, 1995). PRL is involved in more than 300 biological activities ranging from reproduction, growth, and metabolism to behavior and immune responses (Nicoll et al., 1986). PRL exerts its effects by binding to its membranebound cell surface receptor (PRL receptor, PRLR). Its binding sites or receptors are widely distributed throughout vertebrates (Bole-Feysot et al., 1998). PRLRs are characterized by their capability of activating janus kinase 2 and signal transducers and activators of transcription, and they are also included in a larger family known as the cytokine class-1 receptor superfamily, which currently has more than 20 members (Thompson et al., 1997; Bole-Feysot et al., 1998; Fleenor et al., 2006). The absence of PRLR in female mice results in reduced ovulation and fertilization and multiple reproductive abnormalities. PRLR is also important for oocyte maturation (Bole-Feysot et al., 1998; Kelly et al., 2001). In chickens, previous studies have suggested that the PRLR gene was attractive as a candidate gene for broodiness in chicken. Dunn et al. (1998) have mapped the chicken PRLR gene as a candidate gene for the control of broodiness, because a major gene involved in susceptibility to broodiness is thought to reside on the chicken $\mathrm{Z}$ chromosome and manifest as a sex-linked trait. However, associations between variations of the PRLR gene and egg production traits in chickens have not been reported.

Egg productivity is the most important economic trait in egg-laying poultry (Kim et al., 2004). Endocrine and environmental factors such as length of photoperiod and feeding allowance can influence egg production (Lewis and Gous, 2006). However, a genetic factor would be a prerequisite. Egg production is a polygenic inheritance trait with low to moderate heritability depending on the period involved, a major opportunity for improvement in this trait lies in the period after 40 weeks of age (Emsley, 1997; Luo et al., 2007). In traditional breeding, genetic improvement based on estimated breeding values requires extensive data from a variety of sources. The candidate gene approach is a cost-effective means of investigating associations of gene polymorphisms and quantitative trait loci responsible for variations in traits of interest (Rothschild and Soller, 1997; Linville et al., 2001). Many studies have been carried out to identify associations between candidate gene SNPs and egg production traits (Xu et al., 2010, 2011; Huang et al., 2011; Xiao et al., 2011). However, more candidates are needed for marker-assisted selection.

The objective of this study was to evaluate variations of the PRLR gene in Erlang Mountainous chickens (a Sichuan native chicken population) and to investigate the association of these polymorphisms with egg production traits. The candidate gene (PRLR) was screened for polymorphisms using a pooled DNA sequencing approach. Subsequently, mutations in the gene were genotyped using polymerase chain reaction-single-strand conformation 
polymorphism (PCR-SSCP) and direct sequencing methods, and the genetic effects of the mutations on egg production traits were evaluated.

\section{MATERIAL AND METHODS}

\section{Chicken populations and trait measurement}

The Erlang Mountainous chicken is a cultivated breed developed from local chicken breeds in the Sichuan Province in China (Xiao et al., 2011). A population comprising 396 female individuals (SD01 strain $[\mathrm{N}=196]$ and SD02 strain $[\mathrm{N}=200]$ ) from one hatch was used for association analyses in the present study. The birds were raised under the same living conditions and received the same feed. All females were housed individually in laying cages after they reached 90 days of age, and their egg production was observed and recorded daily at $1600 \mathrm{~h}$. The number of eggs produced from 90 to 300 days of age was calculated individually. Egg production traits in this study included the age at first egg (AFE), body weight at first egg (BWFE), weight at first egg (WFE), total number of eggs at 300 days of age (EN), body weight at 300 days of age (BWTA), and egg weight at 300 days of age (EWTA). All animal experiments were conducted in accordance with laws of the People's Republic of China regarding animal protection.

\section{DNA extraction, PCR amplification, identification of polymorphisms, and genotyping}

Total DNA of all samples was phenol extracted from serum following standard procedures (Sambrook et al., 1989). The DNA pool was constructed from 60 samples (every strain including 30 females) containing 100 ng DNA from each individual. We used the Primer Premier 5.0 software and the complete DNA sequence of the Gallus gallus PRLR gene (GenBank accession No. AY547323.1) to design 3 pairs of primers (P2, P4, and P5) for the identification of SNPs (P2, P4, and P5) in 3 fragments of the PRLR gene (synthesized by Shanghai Sangon Biological Engineering Technology \& Services Co. Ltd., China; Table 1). PCR amplification was performed in 50- $\mu \mathrm{L}$ volumes containing $25 \mu \mathrm{L} 2 \mathrm{X}$ Taq PCR MasterMix (TianGen Biochemical Technology Co. Ltd., Shanghai, China), $2.5 \mu \mathrm{L} 10 \mathrm{pmol} / \mu \mathrm{L}$ of each primer, $3 \mu \mathrm{L}$ pooled genomic DNA, and double-distilled $\mathrm{H}_{2} \mathrm{O}$ to $50 \mu \mathrm{L}$. DNA was amplified using a 4-min denaturing step at $94^{\circ} \mathrm{C}$ followed by 35 cycles of $94^{\circ} \mathrm{C}$ for $30 \mathrm{~s}, \mathrm{n}^{\circ} \mathrm{C}$ for $45 \mathrm{~s}$ (n was the annealing temperature shown in Table 1 ), $72^{\circ} \mathrm{C}$ for $1 \mathrm{~min}$, and a 10 -min final extension at $72^{\circ} \mathrm{C}$. PCR products of the pooled DNA samples were sequenced, and SNPs were identified using sequence traces.

\begin{tabular}{|c|c|c|c|c|c|}
\hline Primer name & Primer sequence & $\begin{array}{c}\text { Annealing } \\
\text { temperature }\left({ }^{\circ} \mathrm{C}\right)\end{array}$ & Location $^{\mathrm{a}}$ & Length $^{\mathrm{b}}(\mathrm{bp})$ & Genotyping method \\
\hline P1 & $\begin{array}{l}\text { F: 5'-GAGGAATGGGAGGTAAGGAT-3' } \\
\text { R: 5'-CTGACAGAACGAGAGGGAAC-3' }\end{array}$ & 55.0 & $+14868 \sim+15154$ & 287 & Sequencing \\
\hline P2 & $\begin{array}{l}\text { F: 5'-TCTGGATTCAATACCAACTT-3' } \\
\text { R: 5'-GTTTGATGAAATTTACAGCTA-3' }\end{array}$ & 48.5 & $+17538 \sim+17809$ & 272 & Sequencing \\
\hline P3 & $\begin{array}{l}\text { F: 5'-ACACACAAGGAAACAGACAGT-3' } \\
\text { R: 5'-ATAGGCAAACATAGGAGGC-3' }\end{array}$ & 51.5 & $+20775 \sim+21047$ & 273 & SSCP and sequencing \\
\hline P4 & $\begin{array}{l}\text { F: 5'-CAAATTCCAAAGGTGCAAAG-3' } \\
\text { R: 5'-AAGGCAGGAGGTGATACAGA-3' }\end{array}$ & 55.0 & $+14646 \sim+15421$ & 776 & - \\
\hline P5 & $\begin{array}{l}\text { F: 5'-ATAATCCCTACTGTTAGTAGTGAA-3' } \\
\text { R: 5'-TGATTGTATTTGATCCATTCT-3' }\end{array}$ & 50.0 & $+20553 \sim+21695$ & 1143 & - \\
\hline
\end{tabular}

Referred to the locations in the PRLR gene, the first nucleotide of translation start codon was designated as +1 ; blength of PCR products. 
Three pairs of primers (P1, P2, and P3) were used for individual genotyping. Because the SCCP method has low efficiency and the banding pattern of SSCP is difficult to separate when more than one genotype occurs in some polymorphic fragments, we used the SSCP method only to identify genotypes at the $\mathrm{P} 3$ locus and sequenced all the products of the $\mathrm{P} 1$ and $\mathrm{P} 2$ primers to get accurate results. SSCP analysis was performed according to the method described by Orita et al. (1989). The PCR products of P1 and P2 loci and those of the P3 locus, which represented different PCR-SSCP genotypes including 2 homozygotes, were purified and sequenced using the ABI 3730 automated sequencer from both directions (Applied Biosystems, Carlsbad, CA, USA).

To ensure that the sequenced fragments of DNA were our targeted sequence, we carried out a Basic Local Alignment Search Tool similarity search in the National Center for Biotechnology Information database before sequence analysis. Sequences of the 3 PRLR gene fragments were edited and aligned using DNASTAR (DNASTAR Inc., Madison, WI, USA).

\section{Statistical analysis}

Data were analyzed using the general linear model procedures of SAS (SAS Institute Inc., Cary, NC, USA). The following linear equation was applied to analyze the genetic effects of PRLR:

$$
Y=u+G+B+B \times G+e
$$

where $Y$ was the trait measured in the chickens, $u$ was the population mean, $e$ was the random error, $B$ was the fixed effect of strain, $G$ was the fixed effect associated with the genotype, and $B \times \mathrm{x} G$ was the effect of interaction between strains and genotypes. Multiple comparisons were conducted with least square means.

\section{Haplotype construction}

Haplotypes were constructed based on 6 SNPs in all 396 experimental chickens using the PHASE 2.0 program (Stephens et al., 2001). The program reconstructed haplotypes from the population data. Genetic effects of the haplotypes on egg production traits were evaluated with the mixed model mentioned above.

\section{RESULTS}

\section{Identified SNPs of the chicken PRLR gene}

We directly sequenced all of the PCR products of the P1 and P2 loci and the polymorphic fragments based on SSCP banding patterns of the P3 locus (Figure 1). Two nucleotide transitions (G14952A and G14984A) and 1 transversion (A14969C) were detected at the P1 locus. Two mutation sites at the P2 locus were G17560A and T17626A. Only 1 nucleotide substitution (T20868C) was detected at the P3 locus (Figure 2). As mentioned above, the chicken PRLR gene is located on the $\mathrm{Z}$ chromosome, so hens cannot be heterozygotes. From the sequencing results, we found that the P1 locus has 3 SNPs and the 2 SNPs at P2 are linked. 
Only 2 genotypes were detected at each locus - GAG and ACA at the P1 locus, GT and AA at the $\mathrm{P} 2$ locus, and $\mathrm{T}$ and $\mathrm{C}$ at the $\mathrm{P} 3$ locus.

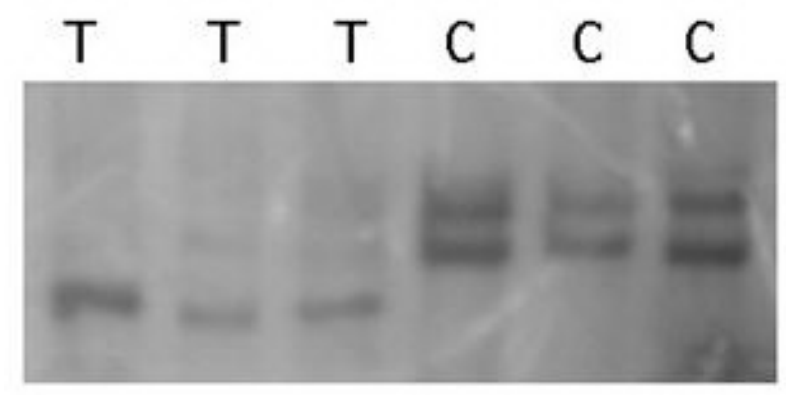

Figure 1. PCR-SSCP band patterns of the P3 locus of the chicken prolactin receptor (PRLR) gene.
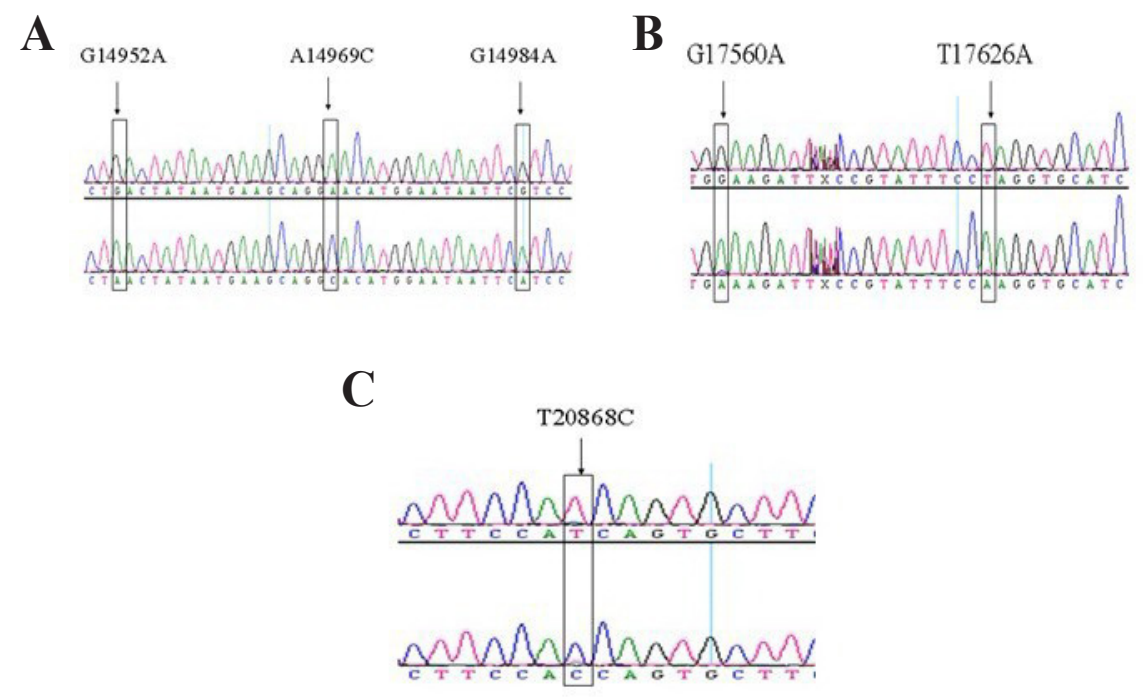

Figure 2. Sequencing analysis of the PRLR gene. A. B. C. Partial sequencing results of the P1, P2 and P3 loci, respectively; arrows indicate mutation sites.

\section{Analysis of genotype frequencies of the PRLR gene in 2 chicken strains}

The frequencies of the 6 genotypes in the SD02 and SD03 strains are shown in Table 2. Genotype frequencies of ACA (P1), AA (P2), and T (P3) in the Erlang Mountainous chicken population were the highest at $0.7172,0.5530$, and 0.6237 , respectively. The average polymorphism information content (PIC) of the 3 loci ranged from 0.3234 at the P1 locus to 0.3722 at the P2 locus (see Table 2). The highest PIC of the 3 loci in 2 strains was 0.3725 at the P3 locus in strain SD03. With the exception of the lowest PIC, $0.2276(<0.25)$ at the P1 locus in strain $\mathrm{SD} 03$, all the other genotypes showed moderate polymorphism. 


\begin{tabular}{|c|c|c|c|c|c|c|c|c|c|c|}
\hline \multirow[t]{2}{*}{ Strains } & \multirow[t]{2}{*}{ No. } & \multicolumn{2}{|c|}{$\mathrm{P} 1$} & \multirow[t]{2}{*}{ PIC } & \multicolumn{2}{|c|}{$\mathrm{P} 2$} & \multirow[t]{2}{*}{ PIC } & \multicolumn{2}{|c|}{ P3 } & \multirow[t]{2}{*}{ PIC } \\
\hline & & GAG & $\mathrm{ACA}$ & & GT & $\mathrm{AA}$ & & $\mathrm{T}$ & $\mathrm{C}$ & \\
\hline SD02 & 196 & 0.4133 & 0.5867 & 0.3674 & 0.2602 & 0.7398 & 0.3109 & 0.8010 & 0.1990 & 0.2680 \\
\hline SD03 & 200 & 0.1550 & 0.8450 & 0.2276 & 0.6300 & 0.3700 & 0.3575 & 0.4500 & 0.5500 & 0.3725 \\
\hline Total & 396 & 0.2828 & 0.7172 & 0.3234 & 0.4470 & 0.5530 & 0.3722 & 0.6237 & 0.3763 & 0.3592 \\
\hline
\end{tabular}

\section{Association of polymorphisms with egg production traits}

The results of the general linear model analysis of associations between PRLR gene polymorphisms and egg production traits were analyzed and the least means $\pm \mathrm{SE}$ are shown in Table 3. For the P1 locus, individuals with genotype GAG had greater BWFE but lower EN than those with genotype ACA $(\mathrm{P}<0.01)$. SNPs at the P2 locus were associated with EWTA $(\mathrm{P}<0.05)$. No egg production traits were significantly association with the genotypes at the $\mathrm{P} 3$ locus in our research.

\begin{tabular}{|c|c|c|c|c|c|c|}
\hline \multirow[t]{2}{*}{ Locus traits } & \multicolumn{2}{|c|}{$\mathrm{P} 1$} & \multicolumn{2}{|c|}{$\mathrm{P} 2$} & \multicolumn{2}{|c|}{$\mathrm{P} 3$} \\
\hline & $\mathrm{GAG}(\mathrm{N}=112)$ & $\mathrm{ACA}(\mathrm{N}=284)$ & GT $(\mathrm{N}=177)$ & $\mathrm{AA}(\mathrm{N}=219)$ & $\mathrm{T}(\mathrm{N}=247)$ & $\mathrm{C}(\mathrm{N}=145)$ \\
\hline BWFE (g) & $2569.77 \pm 31.62^{A}$ & $2454.11 \pm 18.09^{\mathrm{B}}$ & $2532.31 \pm 25.01$ & $2459.44 \pm 21.53$ & $2457.37 \pm 20.02$ & $2515.47 \pm 28.36$ \\
\hline AFE (day) & $165.39 \pm 1.34$ & $164.61 \pm 0.77$ & $164.08 \pm 1.07$ & $164.08 \pm 0.92$ & $162.76 \pm 0.84$ & $165.27 \pm 1.19$ \\
\hline WFE (g) & $40.63 \pm 0.78$ & $40.10 \pm 0.44$ & $39.80 \pm 0.61$ & $40.66 \pm 0.53$ & $39.78 \pm 0.49$ & $40.49 \pm 0.70$ \\
\hline EN (amount) & $85.55 \pm 1.87^{b}$ & $89.78 \pm 1.07^{\mathrm{a}}$ & $86.63 \pm 1.47$ & $89.49 \pm 1.26$ & $89.21 \pm 1.18$ & $88.10 \pm 1.66$ \\
\hline BWTA $(\mathrm{g})$ & $2843.16 \pm 32.16$ & $2844.63 \pm 18.18$ & $2873.53 \pm 25.03$ & $2821.31 \pm 21.54$ & $2812.51 \pm 20.07$ & $2880.35 \pm 27.69$ \\
\hline EWTA (g) & $58.99 \pm 0.52$ & $58.69 \pm 0.30$ & $59.69 \pm 0.42^{\mathrm{a}}$ & $58.49 \pm 0.36^{\mathrm{b}}$ & $58.62 \pm 0.33$ & $59.25 \pm 0.49$ \\
\hline
\end{tabular}

Data are reported as least-square means $\pm \mathrm{SE} . \mathrm{N}=$ number of chickens tested for each genotype; $\mathrm{BWFE}=$ body weight at first egg; $\mathrm{AFE}=$ age at first egg; WFE = weight at first egg; $\mathrm{EN}=$ total number of eggs with 300 days of age; $\mathrm{BWTA}=$ body weight at 300 days of age; EWTA = egg weight at 300 days of age. ${ }^{\mathrm{a}, \mathrm{b}}$ or $^{\mathrm{A}, \mathrm{B}}$ values with no common superscripts within a locus for each genotype differ significantly $(\mathrm{P}<0.05)$ or highly significantly $(\mathrm{P}<0.01)$.

\section{Haplotypes of the PRLR gene in chicken populations}

All of the constructed haplotypes from the 6 SNPs are presented in Table 4. Eight haplotypes were identified in 396 chickens and were designated H1 (GAGGTT), H2 (GAGGTC), H3 (GAGAAT), H4 (GAGAAC), H5 (ACAGTT), H6 (ACAGTC), H7 (ACAAAT), and H8 (ACAAAC). The most common haplotype was H7 (25.51\%); H2 (3.28\%) was the least common haplotype.

The mixed-model analysis indicated significant associations between the haplotypes and some egg production traits (see Table 4). Haplotypes were associated with 5 traits (P values for WFE, EN, BWTA were less than 0.05, and for BWFE and AFE, less than 0.01 ). Because no heterozygous genotypes were present, no diplotypes occurred either. The H2, H3, H5, and H6 haplotypes had positive effects on egg production traits in our experiments. 
Table 4. Association between haplotype and the chicken egg production traits.

\begin{tabular}{|c|c|c|c|c|c|c|c|}
\hline \multirow[t]{2}{*}{ Haplotype } & \multirow[t]{2}{*}{ Frequency $(\%)$} & \multicolumn{6}{|c|}{ Traits } \\
\hline & & $\operatorname{BWFE}(\mathrm{g}) * *$ & $\operatorname{AFE}($ day)** & $\operatorname{WFE}(\mathrm{g})^{*}$ & EN (egg)* & BWTA (g)* & EWTA $(\mathrm{g})$ \\
\hline H1 (GAGGTT) & 8.84 & $2604.46 \pm 62.76$ & $162.61 \pm 2.64$ & $39.96 \pm 1.55$ & $83.39 \pm 3.72$ & $2845.38 \pm 62.30$ & $58.21 \pm 0.96$ \\
\hline H2 (GAGGTC) & 3.28 & $2660.92 \pm 154.58$ & $169.42 \pm 6.51$ & $\overline{38.58 \pm 3.81}$ & $\overline{86.25 \pm 9.16}$ & $3043.00 \pm 153.45$ & $60.75 \pm 2.38$ \\
\hline H3 (GAGAAT) & 11.11 & $2432.90 \pm 77.88$ & $162.09 \pm 3.28$ & $43.64 \pm 1.92$ & $88.05 \pm 4.62$ & $2739.75 \pm 76.72$ & $59.28 \pm 1.19$ \\
\hline H4 (GAGAAC) & 5.05 & $2592.90 \pm 67.79$ & $168.15 \pm 2.85$ & $43.17 \pm 1.67$ & $87.10 \pm 4.02$ & $2880.83 \pm 66.78$ & $\underline{57.90 \pm 1.21}$ \\
\hline H5 (ACAGTT) & 17.17 & $2470.25 \pm 41.59$ & $161.00 \pm 1.75$ & $40.07 \pm 1.02$ & $88.42 \pm 2.52$ & $2797.53 \pm 41.29$ & $58.90 \pm 0.82$ \\
\hline H6 (ACAGTC) & 15.40 & $2483.99 \pm 69.32$ & $171.76 \pm 2.92$ & $41.51 \pm 1.71$ & $86.07 \pm 4.11$ & $2921.55 \pm 68.34$ & $61.53 \pm 1.06$ \\
\hline H7 (ACAAAT) & 25.51 & $2405.43 \pm 32.66$ & $165.36 \pm 1.38$ & $40.98 \pm 0.80$ & $88.56 \pm 1.94$ & $2848.66 \pm 34.09$ & $58.16 \pm 0.55$ \\
\hline H8 (ACAAAC) & 13.64 & $2491.38 \pm 41.46$ & $161.51 \pm 1.75$ & $39.92 \pm 1.02$ & $88.51 \pm 2.46$ & $2803.44 \pm 40.84$ & $58.56 \pm 0.70$ \\
\hline
\end{tabular}

Data are reported as least-square means \pm SE. Values in bold refer to the effect of advantageous haplotype on egg production traits; values underlined refer to the effect of negative haplotype on egg production traits. BWFE = body weight at first egg; $\mathrm{AFE}=$ age at first egg; WFE = weight at first egg; $\mathrm{EN}=$ total number of eggs with 300 days of age; BWTA = body weight at 300 days of age; EWTA = egg weight at 300 days of age; * and ** indicate that each genotype differ significantly $(* \mathrm{P}<0.05)$ or highly significantly $(* * \mathrm{P}<0.01)$.

\section{DISCUSSION}

Animal reproduction involves the activity of many hormones, chemokines, and cytokines, and their receptors play crucial roles in the regulation of reproduction. Probing balanced selection and breeding for growth, reproduction, immunity, and metabolism in chickens for optimum performance has become a hot topic in research (Ou et al., 2009). The candidate gene approach is becoming increasingly economical and effective for finding candidate genes and quantitative trait nucleotides with significant effects on economically important traits (Kanehisa et al., 2002; Cogburn et al., 2003; Zhu and Zhao, 2007; Kuhn et al., 2008). According to the integration strategies described above, the PRLR gene was effectively selected and used to study genetic associations with egg production traits.

PRL is a pituitary hormone that exerts effects by combining with the PRLR. It regulates important physiological functions ranging from well-known effects in mammalian reproduction to osmoregulation in fish and nesting behavior in birds (Elkins et al., 2000). Recent studies have been focused on PRLR gene polymorphisms of pig, cattle, and other animals. Kmiec and Terman (2006) have studied 6 kinds of boars and found that the PRLR genotype is associated with ejaculate volume, sperm concentration, percentage of live sperm, and number of live sperm in the ejaculate. Serrano et al. (2009) have found that pigs with the BB genotype of the PRLR gene have the most offspring and the most live offspring. Lu et al. (2011) have reported that 2 SNPs within exon 10 of the PRLR gene are associated with milk production traits. These studies suggest that the PRLR gene would be a good candidate gene in the determination of reproductive traits in chickens.

To detect the potential association between the PRLR gene and reproductive traits, we sought SNPs in the chicken PRLR gene in Erlang Mountainous chickens, in which egg mass is presently the primary breeding goal. In this study, we sequenced all of the products of the P1 and P2 loci and detected 6 SNPs of the PRLR gene. The results showed that 3 SNPs at the P1 locus are linked completely, as are 2 SNPs at the P2 locus. The association analysis of genotypes and haplotypes showed that polymorphism of the PRLR gene is significantly associated with egg production traits in Erlang Mountainous chickens. The results indicated that the GAG genotype at the P1 locus was associated with greater BWFE and lower EN, which 
fit with the negative correlation between BWFE and EN. EWTA in GT individuals was found to be significantly greater than that in individuals with the TT genotype at the P2 locus. We used the PHASE 2.0 program to get information on the interaction between various SNPs (Stephens et al., 2001). Thus, both haplotype diversity and the method of SNP selection based on maximizing haplotype diversity were preferred to single SNPs (Huang et al., 2003; Zhang et al., 2004). According to the data on associations of haplotypes with egg production traits, we found that the H2 haplotype had greater BWFE and BWTA; the H6 haplotype had later AFE and greater EWTA. The highest WFE was detected with haplotype H3, and chickens of H5 haplotype produced the most eggs at 300 days of age.

Our results revealed that polymorphism of the PRLR gene is significantly associated with egg production traits in the Erlang Mountainous chicken. Compared with chickens of the other genotypes, those with haplotype ACAGTT (H5) had the superior EN production trait at 300 days of age $(\mathrm{P}<0.05)$ and an earlier AFE $(\mathrm{P}<0.01)$. The mutational population had a superior phenotype in this study, and the results suggest that the PRLR gene is a strong candidate gene that affects egg production traits in this breed. These mutations might be promising for the selection of chickens with advantageous phenotypes.

\section{ACKNOWLEDGMENTS}

Research supported by the National Modern Technology System for the Layer Chicken Industry (\#CARS-41). We thank Yao Zhang and Jiangyuan Li for help in managing the birds and collecting data.

\section{REFERENCES}

Bole-Feysot C, Goffin V, Edery M, Binart N, et al. (1998). Prolactin (PRL) and its receptor: actions, signal transduction pathways and phenotypes observed in PRL receptor knockout mice. Endocr. Rev. 19: 225-268.

Cogburn LA, Wang X, Carre W, Rejto L, et al. (2003). Systems-wide chicken DNA microarrays, gene expression profiling, and discovery of functional genes. Poult. Sci. 82: 939-951.

Dunn IC, McEwan G, Okhubo T, Sharp PJ, et al. (1998). Genetic mapping of the chicken prolactin receptor gene: a candidate gene for the control of broodiness. Br. Poult. Sci. (39 Suppl): S23-S24.

Elkins PA, Christinger HW, Sandowski Y, Sakal E, et al. (2000). Ternary complex between placental lactogen and the extracellular domain of the prolactin receptor. Nat. Struct. Biol. 7: 808-815.

Emsley A (1997). Integration of classical and molecular approaches of genetic selection: egg production. Poult. Sci. 76 : 1127-1130.

Fleenor D, Arumugam R and Freemark M (2006). Growth hormone and prolactin receptors in adipogenesis: STAT-5 activation, suppressors of cytokine signaling, and regulation of insulin-like growth factor I. Horm. Res. 66: 101-110.

Huang HY, Li SF, Zhao ZH, Liang Z, et al. (2011). Association of polymorphisms for nuclear receptor coactivator 1 gene with egg production traits in the maternal line of Shaobo hens. Br. Poult. Sci. 52: 328-332.

Huang Q, Fu YX and Boerwinkle E (2003). Comparison of strategies for selecting single nucleotide polymorphisms for case/control association studies. Hum. Genet. 113: 253-257.

Kanehisa M, Goto S, Kawashima S and Nakaya A (2002). The KEGG databases at GenomeNet. Nucleic Acids Res. 30: 42-46.

Kelly PA, Binart N, Lucas B, Bouchard B, et al. (2001). Implications of multiple phenotypes observed in prolactin receptor knockout mice. Front. Neuroendocrinol. 22: 140-145.

Kim MH, Seo DS and Ko Y (2004). Relationship between egg productivity and insulin-like growth factor-I genotypes in Korean native Ogol chickens. Poult. Sci. 83: 1203-1208.

Kmiec M and Terman A (2006). Associations between the prolactin receptor gene polymorphism and reproductive traits of boars. J. Appl. Genet. 47: 139-141.

Kuhn M, von Mering C, Campillos M, Jensen LJ, et al. (2008). STITCH: interaction networks of chemicals and proteins. 
Nucleic Acids Res. 36: D684-D688.

Lewis PD and Gous RM (2006). Effect of final photoperiod and twenty-week body weight on sexual maturity and early egg production in broiler breeders. Poult. Sci. 85: 377-383.

Linville RC, Pomp D, Johnson RK and Rothschild MF (2001). Candidate gene analysis for loci affecting litter size and ovulation rate in swine. J. Anim. Sci. 79: 60-67.

Lu A, Hu X, Chen H, Dong Y, et al. (2011). Novel SNPs of the bovine PRLR gene associated with milk production traits. Biochem. Genet. 49: 177-189.

Luo PT, Yang RQ and Yang N (2007). Estimation of genetic parameters for cumulative egg numbers in a broiler dam line by using a random regression model. Poult. Sci. 86: 30-36.

Nicoll CS, Mayer GL and Russell SM (1986). Structural features of prolactins and growth hormones that can be related to their biological properties. Endocr. Rev. 7: 169-203.

Orita M, Suzuki Y, Sekiya T and Hayashi K (1989). Rapid and sensitive detection of point mutations and DNA polymorphisms using the polymerase chain reaction. Genomics 5: 874-879.

Ou JT, Tang SQ, Sun DX and Zhang Y (2009). Polymorphisms of three neuroendocrine-correlated genes associated with growth and reproductive traits in the chicken. Poult. Sci. 88: 722-727.

Rothschild MF and Soller M (1997). Candidate gene analysis to detect genes controlling traits of economic importance in domestic livestock. Probe 8: 13-20.

Sambrook J, Fritsch E and Maniatis T (1989). Molecular Cloning: A Laboratory Manual. Cold Spring Harbor Laboratory Press, New York, 931-957.

Serrano AB, Haro JGH, Hori-Oshima S, Espinosa AG, et al. (2009). Prolactin receptor (Prlr) gen polymorphism and associations with reproductive traits in pigs. J. Anim. Vet. Adv. 8: 469-475.

Sinha YN (1995). Structural variants of prolactin: occurrence and physiological significance. Endocr. Rev. 16: 354-369.

Stephens JC, Schneider JA, Tanguay DA, Choi J, et al. (2001). Haplotype variation and linkage disequilibrium in 313 human genes. Science 293: 489-493.

Thompson DL Jr, Hoffman R and DePew CL (1997). Prolactin administration to seasonally anestrous mares: reproductive, metabolic, and hair-shedding responses. J. Anim. Sci. 75: 1092-1099.

Xiao L-H, Chen S-Y, Zhao X-L, Zhu Q, et al. (2011). Association of cellular retinol-binding protein 2 (Crbp2) gene polymorphism with egg production in erlang mountainous chicken. J. Poult. Sci. 48: 162-167.

Xu HP, Shen X, Zhou M, Fang MX, et al. (2010). The genetic effects of the dopamine D1 receptor gene on chicken egg production and broodiness traits. BMC Genet. 11: 17.

Xu HP, Zeng H, Zhang DX, Jia XL, et al. (2011). Polymorphisms associated with egg number at 300 days of age in chickens. Genet. Mol. Res. 10: 2279-2289.

Zhang W, Collins A and Morton NE (2004). Does haplotype diversity predict power for association mapping of disease susceptibility? Hum. Genet. 115: 157-164.

Zhu M and Zhao S (2007). Candidate gene identification approach: progress and challenges. Int. J. Biol. Sci. 3: 420-427. 